\title{
Equity in education in El Salvador
}

\section{Alvaro Carrasco Guzmán}

Fundación Empresarial

para el Desarrollo

Educativo (FEPADE)

San Salvador, El Salvador

aathos@geocities.com

fedape@sal.gbrn.net
In terms of equity of educational opportunities, the region displays great problems, and El Salvador is no exception to this. The analysis given here of the shortcomings in respect of equity of education in that country begins with a general description of the fundamental lines of action proposed in the educational reform process. A study is then made of the differences in access to education, the intergenerational transmission of educational opportunities, and disparities in the quality of education. It is noted that education has an instrumental function -economic reproduction- but it also has a function of promoting change in pursuit of a more equitable society. It is asserted that the contribution education can make to development has its limits, and the effect of poverty on educational opportunities and hence on individuals' real possibilities of getting on in the world is highlighted. Finally, some ideas are put forward for maximizing the contribution of education to the development of El Salvador. 


\section{I}

\section{Introduction}

This article seeks to make a contribution to the consideration of the subject of education and development in El Salvador, in the light of the unequal opportunities offered to social sectors of different economic and social levels. This subject has important ideological and practical implications when considering Salvadorian education and may also be useful for other Latin American countries with similar characteristics, for the problem of educational inequity analysed here in detail coincides in many respects with the situation of most other Latin American countries. The decisive connection which exists between economic and social inequity and educational inequity reveals the current limitations on the contribution that education can make to growth, development and overcoming poverty. The recognition of this connection is also a first step towards rediscovering the role that education can play in society as an agent of change.

In this study, data from El Salvador are used to analyse, from the point of view of equity, aspects relating to the coverage, quality and intergenerational transmission of educational opportunities. The analysis shows the magnitude of the problem and prompts reflection on the limits of the contribution that education can make to development in the present conditions. Finally, the article puts forward some ideas for helping to maximize that contribution.

\section{II}

\section{The role of education and the problem of equity}

From the prevailing standpoint of human and economic development, the various levels of formal education generally tend to be viewed as a fundamental mechanism for promoting the emergence of the new productive individuals needed by the present economic model.

Although partly in agreement with the grounds for the relation between education and development, the position taken in this article is one which conceives education in a broader dimension. It cannot be understood solely as the mechanism for ensuring the reproduction of an economic order which, although generally accepted today as the most functional one, falls far short of achieving a society free from pov-

$\square$ A more extensive version of this study was originally prepared for presentation at the 1998 meeting of the Latin American Studies Association held in Chicago. The author wishes to thank Patricia Craig, Irene Flores, David Bronkema and Alberto Barillas for their valuable comments on the present text. erty and other social scourges. There is no suggestion, however, that the neoliberal model is totally incapable of furthering social development: it is viewed rather as the culmination of a long historical and political process, which can serve as the starting point for achieving a society with higher levels of social justice.

In this view, education must not be seen as a purely reproductive mechanism but rather primarily as a power for change. Education in Latin America cannot be divorced from the quest for innovations and alternatives which can help to improve the way societies operate at present. Education is not a product of the market: the education provided by the State represents a social advance which seeks to provide possibilities for all the inhabitants of the State to progress and for society to develop in the direction chosen by its members, rather than a single direction that cannot be questioned.

If education is defined solely insofar as it relates to the economy, it is reduced to the status of a mere 
instrument, so that the whole question simply becomes how much education, of what type, is needed for economic development and for overcoming poverty. This view, which is at once necessary yet partial, ignores the fact that education is a human right by virtue of which people can reach dimensions of the outside and inside world that will help to bring out their personal potential, and that the educational level of the population is in itself one of the indices of the human development of a nation.

When education is reduced to the level of a mere instrument, there is a risk that it will be stripped of its political and moral elements in favour of the noble cause of economic development. Naturally, under this view the instrument serves to reproduce the model, and if the model is assumed to be just and to ensure development and the elimination of poverty, then the fact of reducing education to the level of an instrument does not offer any problems. If it is assumed that the economic model is not perfect, however, then taking a totally neutral attitude to education is dangerous, because no questions are asked about the grounds and reasons for education. Education does in fact serve political ends, and we must ask ourselves: what should those ends be? A great deal of emphasis has been placed on the need for education to further the principle of productivity, and although in this article we do not deny the importance of this aspect, our proposal is that education should also serve the principles of justice and solidarity. As the data show, social and educational conditions in the Latin American countries, and especially in El Salvador, are profoundly inequitable. Consequently, education should aim at promoting changes in our forms of social coexistence in order to make them more harmonious and solidary.

In Latin America, ${ }^{1}$ the distribution of wealth can serve as a starting-point for analysing the problem of equity. Thus, for example, in 1994 39\% of the population of the region as a whole were in a state of poverty and $17 \%$ were in a situation of extreme poverty. In El Salvador, however, the situation is much more serious, because in $199752 \%$ of the population were below the poverty line and $22 \%$ were in a state of extreme poverty (El Salvador, Dirección General de Estadísticas y Censos, 1998).

\footnotetext{
1 The information given in this section is based on ECLAC,
} 1998.
In addition to the problem of poverty, the region suffers from unequal distribution of wealth among the population. Although there appears to have been a modest trend towards the reduction of poverty in the first half of the 1990s, there have been few changes in income concentration, even in the countries with the highest economic growth rates and the lowest levels of poverty (ECLAC, 1997a, p. 21). This is also the case in El Salvador, where there was no change in income distribution between 1992 and 1995, as reflected in the Gini coefficient of 0.5 for those years (IDB, 1998). These levels make El Salvador one of the Latin American countries with the biggest disparities in income distribution (see comparative data in ECLAC, 1997b, p. 46). Likewise, other indicators show that there is unequal distribution of human development in El Salvador, with the poorest sectors registering less progress than the richest sectors (UNDP, 1997, p. 23).

If we center our analysis on educational aspects, we see that the efforts made over the last 10-15 years to expand the coverage of education have not been reflected in a narrowing of the gaps between the different social strata. According to data for the 1980s and first half of the 1990s on the urban areas of 11 Latin American countries, the differences in the proportions of young people between 20 and 24 years of age with 12 years' schooling from households with different levels of educational capital remained practically unchanged over this period.

Other data indicate that in the countries of the region between $30 \%$ and $45 \%$ of all households can be classified as being vulnerable to poverty, while only $10 \%$ of the households possess most of the economic and educational capital. Of the total number of young people between 20 and 24 years of age coming from households that are vulnerable to poverty, $80 \%$ are lagging behind at school or have dropped out altogether, whereas less than $40 \%$ of young people from households with economic and educational capital are in this situation.

Quite apart from the inequalities in terms of access to education and number of years of schooling, the educational differences between students from different economic and social levels become still more marked when the unequal quality of the education received is taken into account. A quantitative indicator which can be used as an approximation to the quality of education is the performance in standardized learning tests. The regional-level data register 
big disparities between the public and private sectors: whereas most students in the public sector only manage to successfully cover some $50 \%$ of the official curriculum, the average for students enrolled in private schools is close to $100 \%$ (ECLAC, 1998, p. 70). In Chile, which was one of the countries with the highest economic growth rate in the 1990s and has one of the highest levels of years of schooling, learning tests have shown that the most important factor affecting educational performance is the economic and social level of the students' families (PIIE/UNICEF, 1995).

Furthermore, social mobility has long been linked with the opportunity to gain access to more and better education. This link, which is indisputable in theory, runs into serious obstacles in reality, one of the most important of which is the very situation of poverty which it is desired to overcome.

In Latin America, the average number of years of schooling has been raised generation by generation. Only a small proportion of young people, however, manage to rise significantly above the educational level of their parents. Thus, while on average young people have three years more schooling than their parents, only a third of urban young people and one-tenth of rural youth have managed to exceed the educational level of their parents and attain a level of basic educational capital equal to 12 years' schooling (ECLAC, 1998, p. 60). Of the total, $47 \%$ of urban young people and $73 \%$ of rural youth neither exceed the educational level of their parents nor reach the basic educational target level. ${ }^{2}$

The figures bearing witness to the inter-generational transition in terms of opportunities are also reflected in the opinions of those consulted on this matter. Some data from Chile, for example, seem to show that the views of the parents interviewed regarding the probable future of their children are influenced to a large extent by the quality of the school they attend, which largely depends on the possibility of going to a paid private school (UNDP, 1998, p. 179).

To sum up: "The persistent lack of equity in terms of access to education based on social background shows that, to a large extent, opportunities for well-being are shaped by the pattern of inequality that prevailed in the previous generation" (ECLAC, 1998, p. 65).

\section{III}

\section{The educational reform process in El Salvador and policies on equity}

Now that the Latin American context has been outlined, the analysis will center on the particular case of El Salvador, which, as we shall see, displays tendencies similar to those of the region as a whole. In the past, there has been an endemic situation of social inequity in that country, which was one of the main causes of the civil war of the 1980s. The peace accords were achieved when efforts were made to put an end to violence and transform Salvadorian society through the creation of democratic institutions and juster living conditions for the mass of the population. On the educational level, that country's experience in carrying out reforms is particularly interesting because it has received substantial international support and has made efforts to match the development and educational models prevailing in international circles.
In 1993, Harvard University, the "José Simeón Cañas" Central American University (UCA) and the Salvadorian Educational Development Foundation (FEPADE) made a diagnostic study of the educational sector which marked the beginning of a process of dialogue and reflection in the country on the need to reform the educational system. The study showed the profound shortcomings of the existing system in

\footnotetext{
${ }^{2}$ According to ECLAC calculations (ECLAC, 1997b, p. 66), an analysis of the qualifications of those entering the labour market in the region shows that, at present, completing the secondary cycle and having at least 12 years' schooling is a basic requirement for securing a reasonable level of well-being. In a large number of countries the data show that reaching this educational threshold gives a likelihood of over $80 \%$ that the individuals in question will be able to obtain an income that will allow them to rise above the poverty line.
} 
terms of access and quality at all levels, as well as the inadequacy of the public resources set aside for the educational sector and the poor management of the resources available. It also showed the need to revise and reformulate both the legislation on education and the arrangements for training teachers. In short, the report expressed the urgent need to make radical changes in most areas and levels of the formal educational system.

On the basis of the findings of the UCA/Harvard/ FEPADE study, the Ministry of Education organized a process of consultation with the different sectors of society. It set up the Commission on Education, Science and Development to set forth guidelines for the transformation of education in the country. It also carried out extensive consultations with different organizations through the National Consultative Forum on Educational Reform. The "Consulta '95", designed to collect the views of teachers, parents and students, and the technical experts of the Ministry of Education, together with the consultation of "ANDES 21 de Junio" (the most important professional association of teachers in the country), were other consultation processes that served as a basis for the preparation of the reforms.

With the important background information described above, the Ministry of Education put forward a programme of reforms in what it called the 1995-2005 Ten-Year Plan. The objectives stated in this document are: to improve the quality of education at all its levels; to increase the efficiency, effi- cacy and equity of the educational system; to democratize education; to create new ways of providing services, and to strengthen the formation of human and civic values. The concrete goals set for the decade were: to reduce the rates of illiteracy, teacher absenteeism, and dropping out and repeating courses by students; to increase the coverage of educational services; to involve the educational community in the management of education; to use State resources efficiently, and to provide timely solutions for the problems of educational establishments.

The measures through which the reform programme tries to tackle the specific problem of inequity are: establishment of the Programme of Healthy Schools and the programme for Education with Community Participation (EDUCO); use of the World Food Programme; the Alternative Classrooms programme, and expansion of the school infrastructure and distance education.

In El Salvador, the measures to expand coverage have given priority to rural and poor areas. As a result, coverage has increased at all levels of the lower educational system, but especially in pre-school and basic education.

Among the measures to improve the quality of education, special mention may be made of the Programme of Healthy Schools and the EDUCO programme, because they are based on the principle of positive discrimination. The rest of the measures in the field of the quality of education have applied to all schools more or less equally.

\section{IV}

\section{Equity in education in El Salvador}

In spite of the action taken by the Ministry of Education under the educational reform programme to reduce educational differences in society, there is still an enormous amount of inequity between the different social sectors. Consequently, the first thing to do when considering the measures which have been undertaken and the need for new strategies to overcome the present situation is to recognize the dramatic insufficiency of the efforts made so far (in spite of the substantial achievements in recent years and the fact that they are indeed on the right track), together with the similarity of the situation in El Salvador, in terms of equity, to that of most other Latin American countries.

\section{Equity of access}

The educational situation of the population, as measured by the number of years of schooling, is pretty poor. According to data for 1996 (table 1), 58\% of the population aged six or more have five years' schooling or less, while only $6.1 \%$ have over 12 
TABLE 1

El Salvador: Distribution of the population aged 6 or more, by number of years of schooling, 1996

(Percentages)

\begin{tabular}{|c|c|c|c|c|c|}
\hline $\begin{array}{l}\text { Number of } \\
\text { years of schooling }\end{array}$ & Total & $1^{\text {st }}$ quartile & $\begin{array}{l}\text { s by level of } \\
2^{\text {nd }} \text { quartile }\end{array}$ & $3^{\text {rd }}$ quartile & $4^{\text {th }}$ quartile \\
\hline $0-5$ years & 58.0 & 32.9 & 28.6 & 24.2 & 14.2 \\
\hline $6-9$ years & 24.1 & 14.9 & 23.1 & 31.7 & 30.3 \\
\hline $10-12$ years & 11.7 & 5.3 & 12.8 & 29.7 & 52.3 \\
\hline Over 12 years & 6.1 & 2.7 & 4.7 & 15.0 & 77.5 \\
\hline Others $^{\mathrm{a}}$ & 0.0 & 47.4 & 52.6 & - & - \\
\hline
\end{tabular}

Source: El Salvador, Dirección General de Estadísticas y Censos (1997).

"Includes the categories "special education" and "not known".

TABLE 2

El Salvador: Proportion of children attending school, by age and income group, 1991 and 1996

(Percentages)

\begin{tabular}{|c|c|c|c|c|c|c|c|c|c|c|c|c|}
\hline \multirow{2}{*}{ Age } & \multicolumn{2}{|c|}{5 years } & \multicolumn{2}{|c|}{6 years } & \multicolumn{2}{|c|}{7 years } & \multicolumn{2}{|c|}{13 years } & \multicolumn{2}{|c|}{14 years } & \multicolumn{2}{|c|}{15 years } \\
\hline & 1991 & 1996 & 1991 & 1996 & 1991 & 1996 & 1991 & 1996 & 1991 & 1996 & 1991 & 1996 \\
\hline $1^{\text {st }}$ quintile & 16 & 33 & 30 & 47 & 55 & 70 & 64 & 74 & 53 & 65 & 45 & 53 \\
\hline $2^{\text {nd }}$ quintile & 20 & 37 & 38 & 54 & 62 & 79 & 70 & 82 & 59 & 67 & 52 & 56 \\
\hline $3^{\text {rd }}$ quintile & 36 & 48 & 54 & 65 & 71 & 80 & 74 & 78 & 72 & 74 & 58 & 68 \\
\hline $4^{\text {th }}$ quintile & 53 & 64 & 74 & 83 & 84 & 88 & 86 & 85 & 74 & 82 & 70 & 72 \\
\hline $9^{\text {th }}$ decile & 69 & 83 & 83 & 93 & 90 & 95 & 89 & 90 & 79 & 85 & 81 & 84 \\
\hline $10^{\text {th }}$ decile & 74 & 93 & 85 & 93 & 91 & 100 & 90 & 98 & 87 & 98 & 82 & 94 \\
\hline
\end{tabular}

Source: Reimers (ed.) (1995), p. 71, and El Salvador, Dirección General de Estadísticas y Censos (1997).

years' schooling. Furthermore, the amount of schooling is unequally distributed, depending on people's income levels.

Of the people with five years' schooling or less, $14 \%$ are in the top income quartile and $32.9 \%$ (i.e., twice as many) in the bottom quartile (table 1). If the analysis is by deciles, we find that only $4 \%$ of the people in the richest decile have five years' schooling or less, whereas $14 \%$ of the people in the poorest decile are in that situation. Moreover, the differences are still greater in the case of people with over twelve years' schooling: only $2.7 \%$ of the people in the poorest decile reach that level of education, whereas $77.5 \%$ of the people in the richest decile have access to post-secondary studies.

For the same year, data on the pre-school and school population (4-18 years of age) show that $69 \%$ of that group are attending school, but here too the distribution is unequal, depending on income. In the poorest quintile, $59 \%$ receive some kind of education, whereas in the richest decile the corresponding figure is $89 \%$ (El Salvador, Dirección General de Estadísticas y Censos, 1997).

In a more detailed analysis of inequalities in access to education as a function of household income (table 2), some specific age groups are taken and their evolution over five years is compared (between 1991 and 1996). The data for 1996 show that nine out of ten children aged 5 from the richest homes are attending school, most likely in pre-school education, whereas only three out of ten of the children from the poorest quintile are able to do so. In the case of adolescents aged 15, the proportion remains practically the same for those from the richest decile, while there is a slight increase in the case of those from the poorest quintile, since four out of five are going to school. 
We can also see that access to education has increased for almost all the age groups and income levels considered. The increase is bigger for the 5, 6 and 7-year age groups and for the first two income quintiles and the tenth decile, thus mostly favouring the poorest children, especially those of pre-school age and those starting in the official school system. There has also been a substantial increase in the case of children from the richest decile, but here the increase was most marked for children of 5, 14 and 15 years of age. There have been noteworthy advances in access to basic education since 1991: in the richest sectors they have been most marked in the age groups corresponding to the last grades of basic education, while in the poorest sectors the effect has been most noticeable in the age groups corresponding to pre-school education and the first grades of primary education.

Between 1991 and 1996, the gap between the first income quintile and the tenth decile in terms of the access of 7 year old children to education has narrowed from $36 \%$ to $30 \%$, indicating that the progress has been greatest in the case of the poorest groups, thus reducing the level of inequality, but the gap increases steadily with age, amounting to $41 \%$ for the 15 year old age group. This is partly due to the fact that the measures taken by the Ministry of Education to expand coverage have been aimed primarily at the first basic education cycle (grades 1 to $6)$. Indeed, the analysis of the evolution of enrollment given by that Ministry shows significant advances in coverage at the basic level, but less impressive achievements in secondary education (Carrasco and Fernández, forthcoming).

Inequalities in access to education also depend on whether the area of residence is urban or rural. For the total population between 7 and 18 years of age, the level of access to education is $74 \%$, but analysis by areas of residence shows that while $83 \%$ of young people of all ages from urban homes attend school, the corresponding figure for rural areas is only $66 \%$. Furthermore, as in the case of the comparison by income brackets, the differences between urban and rural areas are greater in the final years of the 7-18 age group: the system becomes more inequitable as the age and school grades of the students rise (FEPADE, 1997).

The disparities are maintained at the higher levels of the educational system. Thus, in 1996, out of every 100 young people in the second year of secondary education, 40 came from the richest decile
FIGURE 1

El Salvador: Link between supply/demand
for education and reasons for

not studying, by age groups

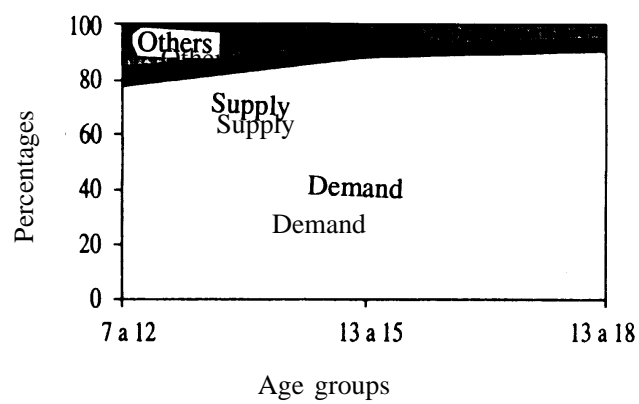

Source: FEPADE (1998), p. 76.

but only 10 came from the poorest decile. Among those who report that they are in their first year of university studies, only $2.5 \%$ come from the poorest quartile, whereas $62 \%$ come from the richest quartile. Of all university students, only $2 \%$ come from the poorest quintile, while $30 \%$ come from the richest decile: these figures are not significantly different from those for 1991, when the respective percentages were $2.35 \%$ and $31.67 \%$ (Reimers, ed., 1995, p. 72).

With regard to differences by sex, the educational situation of women appears to be unfavourable when the total population is considered, for this includes segments resulting from previous educational systems which strongly discriminated against women. In the present educational system, however, the situation of young women and girls is equitable as compared with that of males. According to data extending up to 1995 , whereas in the over-60 age group there were $36 \%$ more women than men who had not completed any school grade at all, in the 6-9 age group the difference between the sexes was only $1 \%$, and moreover favoured the female population (Carrasco and Fernández, forthcoming). This equality between the sexes was also observed in the figures on illiteracy and on the percentage of persons of different ages attending school (FEPADE, 1997).

When seeking reasons for the differences in access to education between the different sectors of the population, as classified by income and area of residence, one instinctively thinks of poverty as the explanation. This is backed up by the data collected (El Salvador, Dirección General de Estadísticas y Censos, 1997), as the four reasons for not studying most frequently given by those interviewed were, in order of importance, "high cost" (lack of economic 
FIGURE 2

El Salvador: Educational achievements of young people between

20 and 24 years of age compared with those of their parents, 1996

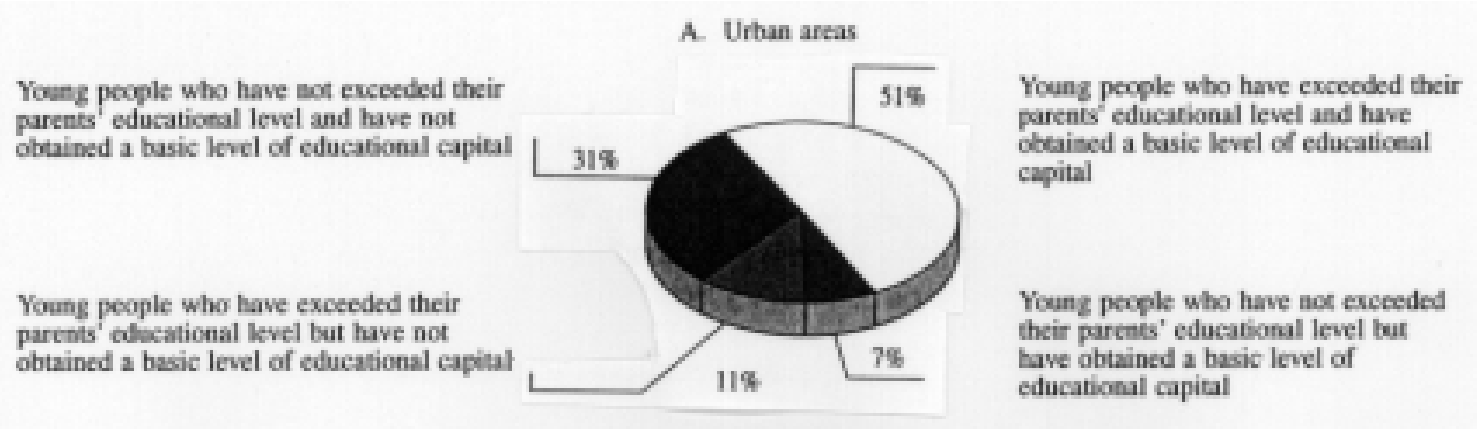

Young people who have exceeded their parents' edscational level and bave cbained a basic kevel of edocational eapital

Young people who have not exeecded their parents' edacational level and have ace obtained a basic level of educational capital
B. Rural areas

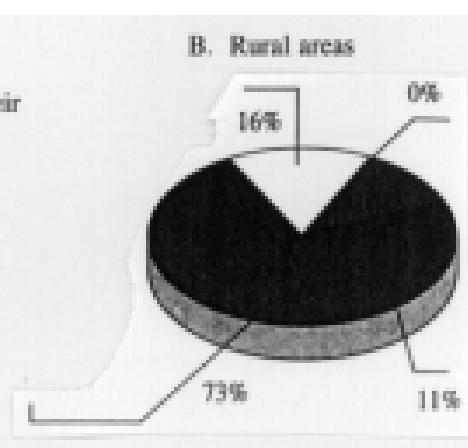

Young people who have not exceeded their parents' colacational level but have cleained a basic level of educational capital

Young people who have exceeded their parents' edacational level but have not obtained a basic level of edacational capital

Source: El Salvador, Dirección General de Estadísticas y Censos (1997).

resources), "need to go to work", "household reasons" and "not worth the trouble". These four reasons are connected with the unfulfilled needs of the population. The answers given indicate that the reasons for not studying are basically connected with the lack of demand rather than the nature and structure of the supply of education. Moreover, the arguments relating to supply are more frequent in the case of the lowest age groups, and as the age of those interviewed rises they relate increasingly to the lack of demand (FEPADE, 1998, p. 76).

According to an opinion survey carried out by the UCA in $1997,19 \%$ of those under 19 years of age were not studying: $46 \%$ of those interviewed explained this situation on the grounds that they did not have the necessary money or resources; $28 \%$ said that the young people concerned did not study because they had to work (including domestic work); $18 \%$ said they had no desire to study, and $7 \%$ gave various other answers. These data show that for $73 \%$ of those interviewed the main cause limiting their access to schooling was poverty.

\section{The inter-generational transmission of educational opportunities in El Salvador ${ }^{3}$}

According to data for 1997, young people between 20 and 24 years of age have an average of 4.7 more years of schooling than their parents: the average schooling of the parents is 4.2 years, while that of their children is 8.9 years. In urban areas, the increase is 5 years (6 years' schooling for the parents and 11 years for their children), and there has also been an increase (albeit smaller) in rural areas, from an average of 2 years' schooling for the parents to an average of 5.8 years for their children aged between 20 and 24. This shows that although both sectors have registered progress, the increase has been greater in urban areas, so that the differences compared with rural areas have increased still further.

\footnotetext{
${ }^{3}$ The procedure for calculating the extent to which young people exceed the education level of their parents was effected by replicating the model developed by ECLAC (1998, p. 61).
} 
The average increase in the number of years of schooling is naturally due to the contribution of the $49 \%$ of young people who have managed to surpass the educational level of their parents, since the remaining $51 \%$ failed to do so. Within these two categories, it is also important to determine what percentage of the population of El Salvador have managed to rise above the basic educational threshold that increases their likelihood of earning sufficient income to live decently. In this respect, we find that only $4.4 \%$ of the population between 20 and 24 years of age, although failing to exceed the educational level of their parents, nevertheless managed to study for 12 years or more. In contrast, $46 \%$ of young people neither exceeded the level of their parents nor reached the threshold level of basic education needed to provide a reasonable level of well-being. Only $36.6 \%$ of young people manage to exceed the educational level of their parents and also acquire the necessary basic educational capital: only they will have a chance of upward social mobility on the basis of their educational capital; $12.7 \%$ exceed the educational level of their parents, but not by a sufficient margin to obtain even 12 years' schooling.

The situation is also inequitable as between urban and rural areas. In urban areas, $51 \%$ of the young people manage to exceed the educational level of their parents and also complete 12 or more years' schooling, whereas only $16 \%$ of rural young people do so (figure 2). Furthermore, $73 \%$ of rural young people neither exceed the educational level of their parents nor complete 12 years' schooling, while a further $11 \%$, although they exceed their parents' educational levels, do not manage to acquire the necessary basic educational capital.

The data thus indicate that in El Salvador there is only a low level of inter-generational educational improvement, especially in the poor sectors of society. For much of the population, there are few possibilities of exceeding the educational levels of their parents and obtaining sufficient educational capital to enable them to attain a better level of living. The educational achievements of the new generations in terms of number of years of schooling are determined to a large extent by the pattern of inequalities of the preceding generation.

\section{Equity as regards quality of education}

For a large number of people, their chances of improving their level of living are limited by their scant possibilities of attending school. Despite persistent problems of equity, however, the educational system is nevertheless tending to increase its coverage. Although the task of providing access to education is still an enormous challenge for society, the question of the quality of the education provided is also of special interest to those who, having gained access to the school system, hope to receive an education which is sufficiently good to allow them to improve on the living conditions of their families of origin. In El Salvador the differences in the quality of education are enormous, as shown by the results of the performance and repetition tests given below.

\section{a) Differences in performance in the Learning Achievement Tests}

One of the measures taken in conjunction with the preparation of the new curriculum was the development of Learning Achievement Tests and their application since 1993 to a sample of pupils from the third and fifth grades. These tests evaluate on a points basis the degree of fulfillment of the objectives of the official programmes. In mathematics, the maximum number of points is 10, and in language, 9 .

According to data for 1994 and 1995, even in the best of cases the average third and fifth grade pupils in the country's schools had not fulfilled even $40 \%$ of the learning targets in language and mathematics. Complementary comparative analyses revealed that pupils in urban areas had a slightly better average than in rural areas, while the performance of the pupils of EDUCO schools was even worse than that of the pupils of non-EDUCO rural schools (El Salvador, Ministerio de Educación, 1996).

Of course, the performance of the students, like their access to education, varies according to their families' income. Thus, for example, the comparisons between public and private schools also reflect the tendencies observed in other countries. In mathematics, the average for students in private schools is 2.15 points higher than in public schools, while in language the private schools are 1.5 points higher. ${ }^{4}$

\footnotetext{
${ }^{4}$ The difference in measurements is statistically significant in the case of both subjects. The Statistical Package for Social Sciences (SPSS) gave a result of $\mathrm{P}=0.000$. These analyses were made with information taken from the data base of the Learning Achievement Tests applied in 1996.
} 
Finally, a study carried out by professionals of the Ministry of Education and FEPADE (FEPADE/El Salvador, Ministerio de Educación, 1998) examined the factors influencing the performance in Learning Achievement Tests, using multiple regression analysis. The model included a set of factors alterable by actions of the educational system and a group of factors not directly alterable by immediate actions of the system. Among the variables were teaching experience, the educational level of the teacher, an economic indicator of the family, and an indicator of the level of development of the municipality (an indicator of the unsatisfied basic needs in the municipality). The language model had a value of $R^{2}=0.28$ and the model for mathematics had a value of $R^{2}=$ $0.30 .{ }^{5}$ According to this regression analysis, students in private schools tend to obtain 0.33 points more than those in public schools in language and 4.0 points more in mathematics. Furthermore, it can be calculated from the results of the regression analysis that in mathematics, students from one of the poorest municipalities (with the largest number of unsatisfied basic needs) obtain 3.02 points less than students from one of the richest municipalities.

The study in question concludes that "in both subjects the indicators which individually help most to explain the performance in the Learning Achievement Tests were those related with the social, economic and cultural conditions of the populations attending those schools (sector and area where school is located, economic and social conditions of the students' families, level of poverty of the municipality in which the school is located). Students from families of lower economic and social levels, attending public-sector schools in the poorer municipalities, are at a disadvantage in terms of performance" (FEPADE/El Salvador, Ministerio de Educación, 1998, p. 2).

These data indicate that in general, as measured by the present learning achievement tests, the performance of Salvadorian students is very poor. They also show that, as in most Latin American countries, the performance of the poorest students is much lower than that of students in a better economic and social situation. Students from the upper economic and social strata learn more and are thus better prepared to take advantage of secondary and tertiary ed-

\footnotetext{
${ }^{5}$ Both models are statistically significant: $\mathrm{F}=0.000$.
}

ucational opportunities and perform well in their working life in the future.

The views of the population bear out the foregoing analyses, because while $54 \%$ of those in the upper economic and social strata say that they are very satisfied with the education received by the minors living in their households, only $30 \%$ of those in the marginal sectors express the same degree of satisfaction. Moreover, $44 \%$ of all those interviewed believe that private education is better than public, while the opposite opinion is held by only $28 \%$ (IUDOP/UCA, 1997).

\section{b) Repetition of grades}

Another indicator which is frequently used to measure the quality of education is the rate of repetition. According to the Multi-Purpose Household Survey, in $19968.8 \%$ of all students of school age were repeating grades. Here, too, however the distribution was unequal (table 3). Thus, for students from the first quintile the rate of repetition was $13.2 \%$, but this rate went down steadily from one quintile to the next until, in the richest quintile, only $3.9 \%$ of the students were repeating grades.

The analysis by area of residence also showed inequality, since in rural areas $12 \%$ of students were repeating, whereas in urban areas only $6.3 \%$ were doing so. Likewise, the rate of repetition in private schools was $5.1 \%$, but in public schools it was $9.8 \%$.

If we analyse repetition by sex, we find that boys repeat grades more than girls: $9.7 \%$ compared with $7.9 \%$. Thus, as in the case of access to schooling, girls were not in a more unfavourable situation than boys.

TABLE 3

El Salvador: Number of students repeating grades, by income groups, 1996

(Percentages)

\begin{tabular}{lc}
\hline Income group & Percentage repeating grade \\
\hline First quintile & 13.2 \\
Second quintile & 11.1 \\
Third quintile & 8.1 \\
Fourth quintile & 6.5 \\
Ninth decile & 4.4 \\
Tenth decile & 3.9
\end{tabular}

Source: El Salvador, Dirección General de Estadísticas y Censos (1997). 
The data show that it is the poorest children who have most difficulty in fulfilling the minimum learning requirements set by schools for moving children up to the next grade. Generally speaking, in absolute terms the requirements of the public schools in this respect are lower than those of private schools, but even so the rate of repetition is higher. This appears to indicate that the poorest parents and public schools have fewer resources for coping with learning difficulties among their children, so that the latter register higher rates of repetition, take longer to complete their basic education and are more likely to drop out altogether, so that there is greater waste of resources by the family and the State on children who repeat grades. In contrast, children from better-off families have less difficulty in completing their studies, do so in a shorter time, and waste fewer resources.

\section{c) Teaching practices}

A study made by the Training Programme for Educational Researchers (PROFINE) in 1997 (PROFINE, 1997) analysed the teaching practices used in the classrooms of 140 public schools, and it was found that most of the teaching practices that still prevail in the classroom place the teacher at the centre of the teaching process. Moreover, although some group work and play practices were observed which represent incipient efforts to comply with the recommendations of the educational reform programme, there was a lack of the theoretical knowledge, technical and practical skills and sense of the significance of teaching needed to put into practice what was sought for in the reform programme. Repetitive activities based on rote learning still predominate, and the requirements are very low.

The study revealed that teaching practices are still far below those that are desirable, so that it is essential to raise the professional level of the teachers and give the schools greater freedom to seek and promote new forms of ongoing professional development.

Unfortunately, the coverage of the study did not permit a comparison of the practices in public schools with those in private educational establishments. It is not possible, therefore, to argue that differences in teaching practices are partly responsible for the differences in performance between students from different economic and social sectors. It can, however, be stated that in the public sector very little is done to promote a form of education which develops the skills demanded by the social and productive sectors. Although there has been some progress, especially at the normative level, the practices used are still very traditional. Indeed, the actions taken by the Ministry of Education to improve teaching have had a much smaller impact than expected. For example, the training given to teachers seems to have done little to change their teaching practices and their pedagogical basis: the books and libraries that now exist are used mainly for the children to copy the texts into their exercise books. The new curriculum is being applied, but without grasping the true sense of the methods proposed.

In addition to these weaknesses in the public schools there are also others that greatly widen the gap with the private schools. Thus, for example, access to computers by pupils in the basic and intermediate levels is still only a dream in the public sector, whereas it has been a reality for several years past in many private schools. Nor is access to Internet a real possibility for students or teachers in the public sector. Laboratories which can foster an interest in the sciences and scientific knowledge are scarce even in the universities, and of course even more so in public basic and intermediate schools. Nor is learning a second language feasible in a public school, whereas in many private schools students graduate knowing a second language and in some cases even a third. 


\section{V}

\section{The limits of education, and ways of maximizing the contribution it can make}

In the 1990s, El Salvador set about the reconstruction of the country. One of the main actions taken in the social field has been the educational reform programme, which began by seeking to strengthen the first grades of the educational system and has gradually been extending to the upper levels. One of the main achievements of this process has been that it has made the nation as a whole aware of the need to improve educational conditions. Now, after several years, the reform process has been reflected in some important achievements. Thus, the coverage of the educational system has been steadily and substantially increased, with a positive bias in favour of the poorest sectors. In spite of the advances which have been made, however, there are still serious limitations on access to the system (above all to pre-school, secondary and higher education), especially for poorer persons. Measures have also been taken to improve the quality of education, but their impact has been less than hoped for, and because of the great problems existing in the educational system and society as a whole, there is still a long way to go in this respect.

Education is seen as one of the main strategies for changing production patterns and securing sufficiently high and sustained growth to allow the population to overcome poverty and obtain better living conditions. However, the poverty of many families largely limits their educational opportunities. Education can only help the country to attain higher levels of development if the population is able to receive a good education regardless of their economic situation. The idea is to generate conditions that will allow all sectors of society to have equal educational opportunities, but that is not the case at present.

The country is still far from maximizing the contribution that education could make to development. Even if the educational system were to expand its coverage to the point where there are enough schools and teachers, and even if the education provided in school were of the highest quality, many children still would not be able to attend school, be- cause their families are poor. Even though education is free, a good percentage of families in the country are hard put to it to generate the income needed to satisfy their basic needs. In the poorest sectors, children who do not attend school do not do so only because of the lack of suitable educational possibilities, but because they need to earn money in order to survive, while other children, although they do manage to attend school, do not enjoy the same backing as children in a better economic situation, so that they gain less advantage from their schooling and their performance is also lower. In the hypothetical case that the educational system were capable of ensuring that all children went to school, regardless of their economic background, there would still be the problem of the enormous gap between the quality of the education received by poor and better-off children, respectively, as well as the disparity between their capacity to take advantage of their learning opportunities.

The educational system faces the challenge of improving the way it operates: that is to say, expanding its coverage and improving its quality, appropriateness and efficiency, while constantly pursuing criteria of equity. From the point of view of development, this would help considerably to ensure growth and progress. However, the contribution that education can make to development does have its limits, which begin where the influence of other social variables starts to be felt. Consequently, in order to improve the situation of the population of El Salvador a number of other measures designed to overcome poverty and inequality are also needed. It is not a question of reviving the violent social disputes of the past, but of bringing about the necessary changes within a climate of democratic coexistence.

Paradoxically, the polarization experienced by the country in the 1980s and the collapse of certain extreme social proposals have meant that in a poor country like El Salvador, with its enormous social disparities, certain social issues of a structural nature have had to be postponed because of the need to be- 
gin a process of true democratization, to reconstruct the country, and to maintain a stable economy. In order for the present economic model to function properly, all members of society must have equal opportunities, otherwise the system would be very unjust and would keep alive many inequalities, even though many families might slowly begin to rise just a little above the poverty line. In the government's actions, education must be given a very important place, but within the context of a set of other measures in the social, economic, political, legal and cultural spheres which go to make up an integrated growth and development policy. It would not be a good thing for Salvadorian society to over-estimate or under-estimate the importance of education in development.

In view of the multidimensional nature of the task faced by that society, education should seek to transmit knowledge and skills from one generation to another not only in order to reproduce the legacy of the previous generation but also in order to raise the level of knowledge and the living conditions of the population: it should thus contribute to the change which, in the case of El Salvador and the other Latin American countries, means seeking fairer forms of social coexistence for all. This is education's role in furthering change: it should stimulate people to reflect on the situation, make adjustments, and create social, economic, political, scientific and cultural proposals. Although this manner of viewing education might seem a mere conceptual consideration, in reality it is much more than that. A form of education committed to the development of society and of the poorest sectors has practical implications for curricula and teaching practices at all levels.

When rethinking the purposes of education in $\mathrm{El}$ Salvador, they must include the promotion of political skills and habits of participation in a free, democratic context. Education, not hunger, must be the breeding-ground for social and political awareness. It is also important to bear in mind that education has an important role in terms of self-realization, so that it is valuable in itself, quite apart from any market-related considerations. It must always be remembered that education is a human right.

With regard to these considerations about the proper understanding of education and its real contribution to the country's development, it may be added that the Salvadorian educational system is far from making its maximum possible contribution to society. In order for the system to be able to fulfill its objectives, various measures are needed, as detailed in the following paragraphs.

In the search for creative but soundly based solutions to the problems of education in El Salvador, it is important to raise the technical capacity of the Ministry of Education. It would be useful to give significant support to the professional development of its technical experts, university professors and researchers, and other professionals in non-governmental organizations active in the field of education. It would be highly advisable to revise the organizational structure, working procedures and systems of incentives of the Ministry and other institutions in order to stimulate professional development and research.

In this connection, a national debate should be promoted among the relevant professionals on the data generated by the system and the resulting ideas and proposals. To this end, the key information in the hands of the Ministry of Education -such as the results of the primary education performance tests and the Test of Learning and Aptitudes for Students Completing their Secondary Education- should be made public in a straightforward and transparent manner. It is true that there is a danger that the results might be used politically for or against the government, but it is also true that there can be no serious reflection in pursuit of solutions if these results are not revealed. Moreover, citizens and social institutions have every right to know how public systems are working. It is therefore necessary to provide more support for social research and evaluation of the educational system.

At the same time, efforts must be continued to expand coverage, especially towards rural areas and the poorest regions. Although much has already been done at the basic level, measures should now be taken to expand coverage at the pre-school and secondary levels. It is also essential to prepare a set of measures to ensure continuity in the post-secondary levels of education for the poorest students. At all levels, high-quality educational services must be developed for the poorer students. The traditional formal educational system is based on social assumptions which are different from those applicable to a large part of the population: it assumes, for example, that all students have the necessary backing to enable them to spend their time attending school. 
As this ideal situation does not exist for a considerable sector of the population, however, and will probably not exist for several decades to come, even in the best of cases, educators should seek new ways of bringing education to the poorest sectors.

Furthermore, much of the working population ceases to have any links with the formal educational system. For example, $14 \%$ of the population of El Salvador are between 20 and 30 years of age and were educated under the educational system that existed before the reform process, and only $11 \%$ of this sector of the population is studying anything (El Salvador, Dirección General de Estadísticas y Censos, 1998). It is therefore essential to coordinate efforts to give those over 20 training opportunities that could raise their productivity.

With regard to improving the quality of education, one of the first measures should be to raise the professional level of teachers. Many training activities have been carried out since 1990, and they have made some contributions, but they have had some questionable aspects and have had little impact on teaching practices (FEPADE, 1998). It is urgently necessary to seek new decentralized forms of professional development for the 28,000 teachers which are economically sustainable and closer to the teaching model that it is desired teachers should follow in their classrooms. With time, technology and distance education could be incorporated in these efforts.

Teachers' training was recently restructured, and the changes have been well received by most sectors, although these changes must of course be continually evaluated in order to detect possible difficulties. At the same time, the faculties of education in the universities must be provided with more resources and with opportunities for the professional development of their professors, which would serve in turn to raise the level of the professionals trained in the universities and the quality of their work.

The poor results obtained in the national learning tests in language and mathematics indicate that specific measures of different types must be taken to gradually overcome these shortcomings. Pedagogical research and experimentation on these subjects are of decisive importance for designing suitable policies. ${ }^{6}$

\footnotetext{
${ }^{6}$ In 1999, for the second year running, FEPADE opened a research fund for investigation into the learning of reading, writing and mathematics.
}

The phenomenon of repetition of grades in $\mathrm{El}$ Salvador must also be studied more closely in order to find out its main causes among the poorer sectors. The resources of the educational system and the students' learning opportunities would be greatly benefited by the application of policies specifically designed to solve this problem.

The educational system has begun a decentralization process, with some degree of success, transferring administrative authority to the regions and, in recent years, to the schools themselves. The present degree of delegation of authority, however, is not sufficient to enable each school to establish its own institutional profile or define, adapt or strengthen teaching processes (Carrasco, Guevara, Hernández and Rodríguez (forthcoming)). In other countries, the decentralization of school and teaching management to the school level has given rise to team work dynamics and the possibility of generating more pertinent and creative activities (Chile, MINEDUC, 1998). A wise measure that the Ministry of Education could apply would be to provide mechanisms, finance and technical assistance for school projects generated on a team basis which involve the community and present valuable and innovative proposals. Measures of this type can have important effects, since in addition to generating a different type of working culture in the educational centres they open up the possibility that the system can learn from the bottom up, from the schools themselves. School decentralization in El Salvador should promote greater autonomy in the educational centres in the medium term (Carrasco, 1998). Naturally, in order to be effective the decentralization process must be accompanied by timely technical support and financial resources to make the initiatives generated in the educational centres viable.

In any policy of decentralization towards the schools themselves, the position of the school director or headmaster is of key importance for promoting participative decision-making, cooperative work and autonomous management. It is therefore necessary to promote special arrangements for the professional development of school directors in such fields as leadership, participation, project preparation and evaluation, and school-community relations (Carrasco, 1998; Carrasco, Guevara, Hernández and Rodríguez (forthcoming)).

(Original: Spanish) 


\section{Bibliography}

Carrasco, A. (1998): Crónica analítica. Comentarios en torno a la presentación del estudio: 'El Salvador: Reforma Educativa'. Análisis del proceso de descentralización, San Salvador, El Salvador.

Carrasco, A. and A. Fernández (forthcoming): La reforma educativa en El Salvador. Informe de El Salvador para el Programa de Promoción de la Reforma Educativa en América Latina y el Caribe (PREAL), San Salvador, El Salvador, Publicaciones FEPADE, Colección Investigaciones.

Carrasco, A., M. Guevara, C. Hernández and M. Rodríguez (forthcoming): Los consejos directivos escolares. Análisis de una estrategia de administración escolar local participativa, San Salvador, El Salvador, Publicaciones FEPADE, Colección Investigaciones.

Chile, MINEDUC (Ministry of Public Educaction) (1998): Manual para la educación básica. Proyectos de Mejoramiento Educativo, Santiago, Chile.

ECLAC (Economic Commission for Latin America and the Caribbean) (1997a): Social Panorama of Latin America, 1996, LC/G.1946-P, Santiago, Chile.

- (1997b): The Equity Gap: Latin America, the Caribbean and the Social Summit, LC/G.1954 (CONF. 86/3), Santiago, Chile.

-(1998): Social Panorama of Latin America, 1997, LC/G.1982-P, Santiago, Chile.

El Salvador, Dirección General de Estadísticas y Censos (1997): Encuesta de hogares de propósitos múltiples, EHPM 1996, San Salvador, El Salvador.

-(1998): Encuesta de hogares de propósitos múltiples, EHPM 1997, San Salvador, El Salvador.

El Salvador, Ministry of Education (1995): Documento III. Lineamientos Generales del Plan Decenal 1995-2005, San Salvador, El Salvador.

- (1996): Informe de evaluación del rendimiento en $3^{\circ}$ y $5^{\circ}$ grados de Educación Básica en lenguaje, matemáticas, estudios sociales y ciencia, salud y medio ambiente, basado en la aplicación nacional de pruebas de octubre de 1995, San Salvador, El Salvador.

FEPADE (Salvadorian Educational Development Foundation) (1997): Los jóvenes en situación de exclusión social. Caracterización de la niñez y adolescencia de 7 a 18 años de El Salvador, San Salvador, El Salvador.

(1998): Memorándum analítico. En la búsqueda de nuevos modelos de desarrollo profesional permanente, San Salvador, El Salvador.

FEPADE/El Salvador, Ministry of Education (1998): Memorándum analítico. Factores asociados al rendimiento. Datos de las pruebas de logros de aprendizaje de lenguaje y matemáticas. Base de datos de 1996, San Salvador, El Salvador.

IDB (Inter-American Development Bank) (1998): Basic Socio-Economic Data, El Salvador, ESDB Query Facility (http://database.iadb.org/esdbweb/scripts/ esdbweb.exe).

IUDOP (Instituto de Opinión Pública)/UCA(Universidad Centroamericana José Simeón Cañas) (1997): Encuesta sobre el sistema educativo y la salud, San Salvador, El Salvador.

PIIE (Interdisciplinary Programme for Educational Research)/UNICEF (United Nations Children's Fund) (1995): Equidad y educación básica en Chile. Análisis de los resultados del SIMCE en $4^{\circ}$ año básico 1992, Santiago, Chile.

PROFINE (Programa de Formación de Investigadores Educativos) (1997): ¿Tú aprendes? ¿Yo enseño?. Discurso y realidad en las escuelas salvadoreñas, San Salvador, El Salvador, Publicaciones FEPADE.

Reimers, F. (ed.) (1995): La educación de cara al siglo XXI. Desafios y oportunidades, San Salvador, El Salvador, Universidad Centroamericana José Simeón Cañas/UCA Editores.

UNDP (United Nations Development Programme) (1997): Human Development Report 1997, New York. (1998): Desarrollo humano en Chile 1998: las paradojas de la modernización, Santiago, Chile. 